\title{
Enhanced photoelectric conversion efficiency of dye-sensitized solar cells by the synergetic effect of $\mathrm{NaYF}_{4}: \mathrm{Er}^{3+} / \mathrm{Yb}^{3+}$ and $\mathrm{g}-\mathrm{C}_{3} \mathrm{~N}_{4}$
}

\author{
Mingqi Yu ${ }^{1}$, Yang $\mathrm{Qu}^{1}$, Kai Pan ${ }^{1}$, Guofeng Wang ${ }^{1 *}$ and Yadong $\mathrm{Li}^{2}$
}

\begin{abstract}
TiO}_{2}-\mathrm{NaYF}_{4}: \mathrm{Er}^{3+} / \mathrm{Yb}^{3+}-\mathrm{C}_{3} \mathrm{~N}_{4}$ composite photoanodes were successfully designed for the first time. The photoelectric conversion efficiency of $\mathrm{TiO}_{2}-\mathrm{NaYF}_{4}: \mathrm{Er}^{3+} / \mathrm{Yb}^{3+}$ $\mathrm{C}_{3} \mathrm{~N}_{4}$ composite cell can result an efficiency of $7.37 \%$, which is higher than those of pure $\mathrm{TiO}_{2}$ cell and $\mathrm{TiO}_{2}-\mathrm{C}_{3} \mathrm{~N}_{4}$ composite cell. The enhancement of the efficiency can be attributed to the synergetic effect of $\mathrm{NaYF}_{4}: \mathrm{Er}^{3+} / \mathrm{Yb}^{3+}$ and $\mathrm{C}_{3} \mathrm{~N}_{4}$. Electrochemical impedance spectroscopy analysis revealed that the interfacial resistance of the $\mathrm{TiO}_{2}$-dye $\mid \mathrm{I}_{3}{ }^{-} / \mathrm{I}^{-}$electrolyte interface of $\mathrm{TiO}_{2}-\mathrm{NaYF}_{4}: \mathrm{Er}^{3+} / \mathrm{Yb}^{3+}-\mathrm{C}_{3} \mathrm{~N}_{4}$ composites cell was much smaller than that of pure $\mathrm{TiO}_{2}$ cell. In addition, the $\mathrm{TiO}_{2}-\mathrm{NaYF}_{4}: \mathrm{Er}^{3+} / \mathrm{Yb}^{3+}-\mathrm{C}_{3} \mathrm{~N}_{4}$ composite cell had longer electron recombination time and shorter electron transport time than that of pure $\mathrm{TiO}_{2}$ cell.
\end{abstract}

Keywords: $\mathrm{NaYF}_{4}: \mathrm{Er}^{3+} / \mathrm{Yb}^{3+}-\mathrm{C}_{3} \mathrm{~N}_{4}$, synergetic effect, luminescence, dye-sensitized solar cells.

\section{INTRODUCTION}

With the increasingly serious energy crisis, more and more people begin to explore new alternative energy. Dye-sensitized solar cells (DSSCs) have received tremendous attention for the development of next-generation solar cells because of their high power conversion, low-cost and environment-friendliness [1-3]. It is well known that the amount of dye adsorption, light harvesting efficiency, and the ability of charge separation and transport are three important factors to improve the photoelectric conversion efficiency of DSSCs [4-8]. In particular, the properties of materials such as excellent light scattering, fast electron transport and large specific surface area play an important role in enhancing the light conversion efficiency of DSSCs $[9,10]$. In order to enhance the photoelectric conversion efficiency of a DSSC, researchers have designed different architectures of $\mathrm{TiO}_{2}$ nanocrystalline films, such as doping of metal and nonmetal elements, surface modifications, and combination with narrow band gap semiconductors [11-13]. In addition, the conduction and valence bands of the rare earth (RE) ion modified $\mathrm{TiO}_{2}$ nanoparticles have higher potentials than those of unmodified $\mathrm{TiO}_{2}$ nanoparticles due to the participation of RE ions in the hybridization orbital of $\mathrm{TiO}_{2}$, which can reduce the probability of recombination of excited electrons and holes to increase the short-circuit current during the operation of the DSSCs.

$\mathrm{RE}$ ions doped luminescent materials usually show unique down-conversion (DC) and up-conversion (UC) properties, which offer the opportunity to improve light harvesting and thereby the efficiency of the solar cells [14-16]. To date, there have been a number of reports on luminescence materials. Among them, fluorides doped with RE ions have low photon energies and high quantum efficiencies, which give them the potential for widespread applications in optical communication, display devices, and solid-state lasers. Especially, $\mathrm{NaYF}_{4}$ is acknowledged as the most efficient luminescence host material at present. However, the incorporation of $\mathrm{NaYF}_{4}: \mathrm{Er}^{3+} / \mathrm{Yb}^{3+}$ into DSSCs can lead to poor charge transfer due to the poor electrical conductivity of $\mathrm{NaYF}_{4}: \mathrm{Er}^{3+} / \mathrm{Yb}^{3+}[17-23]$, which limits the significant enhancement of photoelectric conversion efficiency of DSSCs.

As a new metal-free semiconductor, g- $\mathrm{C}_{3} \mathrm{~N}_{4}$ has attracted increasing attention owing to its excellent mechanical, electrical, thermal, and optical properties, and outstanding potential for energy conversion and storage. Some efforts

\footnotetext{
${ }^{1}$ Key Laboratory of Functional Inorganic Materials Chemistry Ministry of Education, School of Chemistry and Materials Science, Heilongjiang University, Harbin 150080, China

${ }^{2}$ Department of Chemistry, Tsinghua University, Beijing 100084, China

*Corresponding author (email: wanggf_w@163.com)
} 


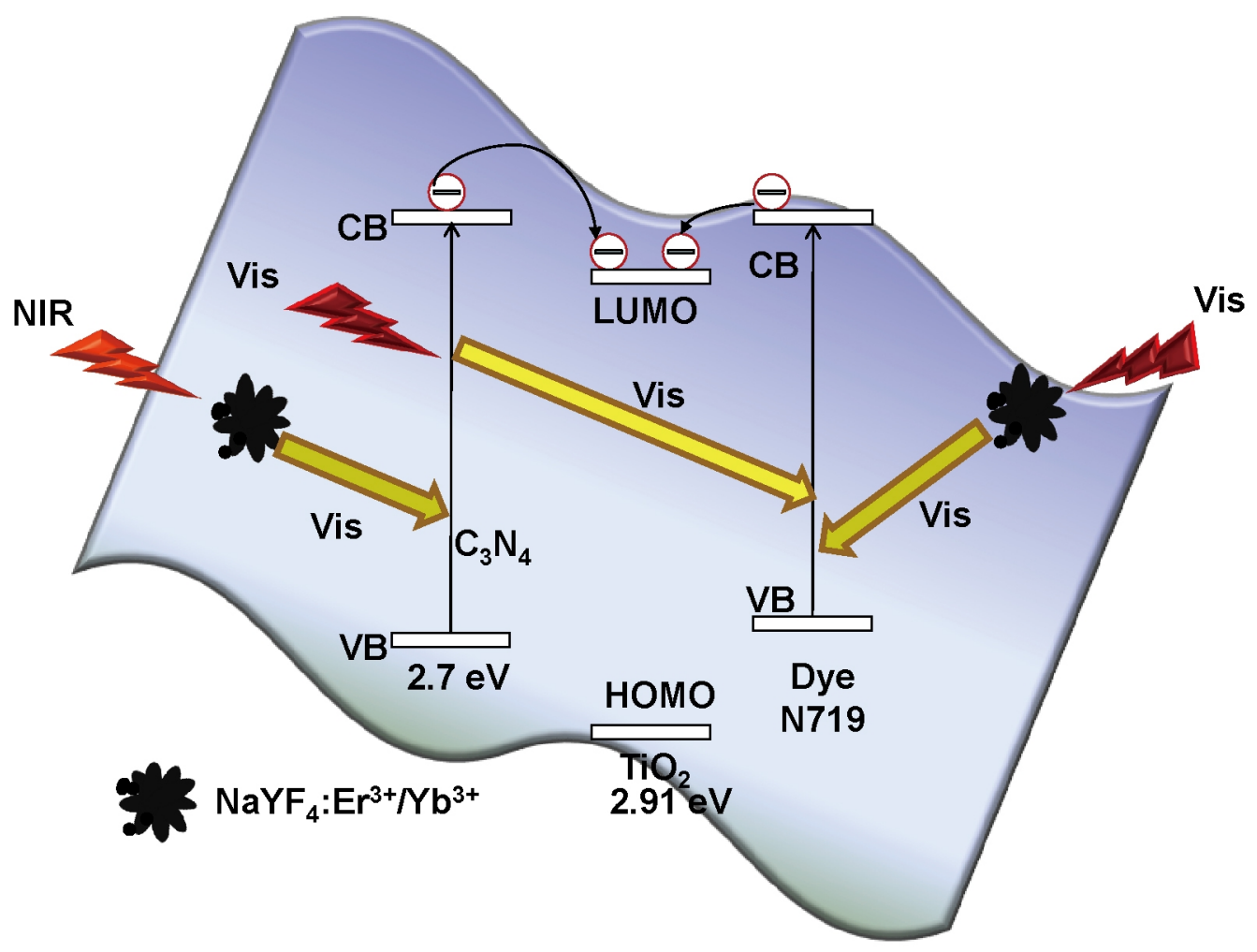

Scheme 1 Mechanism of light harvesting in $\mathrm{TiO}_{2}-\mathrm{NaYF}_{4}: \mathrm{Er}^{3+} / \mathrm{Yb}^{3+}-\mathrm{C}_{3} \mathrm{~N}_{4}$ composite cells.

have been devoted to combining $\mathrm{C}_{3} \mathrm{~N}_{4}$ with a metal or oxide to form heterojunctions because composite materials could present complementary properties. It could be used as a photoanode material in DSSC due to its ability to absorb a large part of visible light. More importantly, $g-\mathrm{C}_{3} \mathrm{~N}_{4}$ has more negative conduction band position than that of $\mathrm{TiO}_{2}$, which may effectively prevent the migration of electrons from $\mathrm{TiO}_{2}$ to the electrolyte [24-26].

As a result, if one can design dual-mode luminescent $\mathrm{TiO}_{2}-\mathrm{NaYF}_{4}: \mathrm{Er}^{3+} / \mathrm{Yb}^{3+}-\mathrm{C}_{3} \mathrm{~N}_{4}$ composite photoanodes, the efficiency of the solar cells can be enhanced due to the synergetic effect of $\mathrm{NaYF}_{4}: \mathrm{Er}^{3+} / \mathrm{Yb}^{3+}$ and $\mathrm{g}_{-} \mathrm{C}_{3} \mathrm{~N}_{4}$.

Based on the above consideration, we prepared a $\mathrm{NaYF}_{4}: \mathrm{Er}^{3+} / \mathrm{Yb}^{3+}-\mathrm{C}_{3} \mathrm{~N}_{4}$ composite by combining the hydrothermal with chemisorption method, which have the ability to improve the efficiency of the solar cells. The high photovoltaic activity of the $\mathrm{TiO}_{2}-\mathrm{NaYF}_{4}: \mathrm{Er}^{3}+/ \mathrm{Yb}^{3+}-\mathrm{C}_{3} \mathrm{~N}_{4}$ composite photoanode is superior to the most reported photoanodes [27-30]. The significantly improved photoelectric conversion efficiency of DSSC is related to the synergetic effect of $\mathrm{NaYF}_{4}: \mathrm{Er}^{3+} / \mathrm{Yb}^{3+}$ nanoparticles and $\mathrm{C}_{3} \mathrm{~N}_{4}$ (Scheme 1). The electron transport and interfacial recombination kinetics were investigated by the electrochemical impedance spectroscopy (EIS) and intensity-modulated photocurrent/photovoltage spectroscopy.

\section{EXPERIMENTAL SECTION}

\section{Preparation of $\mathrm{NaYF}_{4}: \mathrm{Er}^{3+} / \mathrm{Yb}^{3+}$ nanoparticles}

All chemicals used in this paper were analytical grade and used as received without further purification. In a typical synthesis, $0.5 \mathrm{~g}$ polyvinyl pyrrolidone was added to $10 \mathrm{~mL}$ deionized water, and the solution was thoroughly stirred. An aqueous solution of $1.6 \mathrm{~mL} \mathrm{Y}\left(\mathrm{NO}_{3}\right)_{3}, 0.4 \mathrm{~mL} \mathrm{Yb}\left(\mathrm{NO}_{3}\right)_{3}$ and $0.04 \mathrm{~mL} \operatorname{Er}\left(\mathrm{NO}_{3}\right)_{3}$ was added into the above solution under stirring at room temperature for $10 \mathrm{~min}$. Then, 0.212 $\mathrm{g} \mathrm{NaF}$ was added to the above mixture under stirring. Subsequently, the milky colloidal solution was transferred to a $50 \mathrm{~mL}$ Teflon-lined autoclave, and heated at $140^{\circ} \mathrm{C}$ for 10 $\mathrm{h}$. The systems were then allowed to cool to room temperature. The final products were collected by means of centrifugation, washed with deionized water and ethanol, and dried at $80^{\circ} \mathrm{C}$.

\section{Preparation of $\mathrm{NaYF}_{4}: \mathrm{Er}^{3+} / \mathrm{Yb}^{3+}-\mathrm{C}_{3} \mathrm{~N}_{4}$ nanocomposites}

The $\mathrm{C}_{3} \mathrm{~N}_{4}$ was first prepared by heating melamine to $550^{\circ} \mathrm{C}$ 
for $2 \mathrm{~h}$ in $\mathrm{N}_{2}$ atmosphere. An appropriate amount of $\mathrm{C}_{3} \mathrm{~N}_{4}$ was added into methanol then the beaker was placed in a sonifier cell disrupter for $2 \mathrm{~h}$ to completely disperse the $\mathrm{C}_{3} \mathrm{~N}_{4}$. The $\mathrm{NaYF}_{4}: \mathrm{Er}^{3+} / \mathrm{Yb}^{3+}$ powder was added into the above solution and stirred in a fume hood for $24 \mathrm{~h}$. After volatilization of the methanol, an opaque powder was obtained after drying at $100^{\circ} \mathrm{C}$ in $\mathrm{N}_{2}$ atmosphere.

\section{Materials characterization}

The crystal structure was analyzed by X-ray powder diffraction (XRD) patterns obtained by Bruker D8 Advance diffractometer by using $\mathrm{Cu} \mathrm{Ka}$ radiation $(\lambda=1.5406$ $\AA, 40 \mathrm{kV}, 40 \mathrm{~mA}$ ). The size and morphology of the final products were investigated by transmission electron microscopy (TEM, JEOL, JEM-2100) and scanning electron microscopy (SEM). Nitrogen adsorption-desorption isotherms were collected using a Tristar II 3020 surface area and porosity analyzer (Mcromeritics). Thermogravimetry (TG) measurements were carried out on a thermal analyzer (TGA-7, Perkin-Elmer, USA) using a 2-mm internal diameter Teflon tube with a heating rate of $10^{\circ} \mathrm{C}$ per minute under a flow of air. Fourier transform infrared (FTIR) spectra of the samples were recorded at room temperature with a Perkin-Elmer Spectrum one FTIR spectrometer using the $\mathrm{KBr}$ pellet method. UV-vis absorption spectra were determined by a UV-vis spectrophotometer (Shimadzu UV-2550, Tokyo, Japan). The photoluminescence spectra were recorded with a Hitachi F-4600 fluorescence spectrophotometer at room temperature. The UC luminescence spectra were recorded using a Hitachi F-4600 fluorescence spectrophotometer with an adjustable laser $(980 \mathrm{~nm})$ as the excitation source with a fiber-optic accessory. For comparison of the luminescence properties of different samples, the luminescence spectra were measured with the same instrument parameters $(2.5$ $\mathrm{nm}$ for spectral resolution (FWHM) of the spectrophotometer and $400 \mathrm{~V}$ for PMT voltage).

\section{Fabrication of photoelectrodes}

Fabrication of photoelectrode and the assembly of DSSCs: several pastes, from homogeneously mixing $\mathrm{NaYF}_{4}: \mathrm{Er}^{3+} / \mathrm{Yb}^{3+}-\mathrm{C}_{3} \mathrm{~N}_{4}$ and $\mathrm{TiO}_{2}$ (Degussa P25) into 1.5 $\mathrm{mL}$ of $\mathrm{TiO}_{2}$ colloid, were prepared. The $\mathrm{TiO}_{2}$ colloid was prepared following the previously published synthesis procedure [31]. A screen-printed double layer of $\mathrm{TiO}_{2}-\mathrm{NaYF}_{4}: \mathrm{Er}^{3+} / \mathrm{Yb}^{3+}-\mathrm{C}_{3} \mathrm{~N}_{4}$ was used as the photoanode. The first layer of $\mathrm{TiO}_{2}-\mathrm{NaYF}_{4}: \mathrm{Er}^{3+} / \mathrm{Yb}^{3+}-\mathrm{C}_{3} \mathrm{~N}_{4}$ was prepared by a doctor-blade method on the fluorine doped tin oxide (FTO) substrate and then sintered at $450^{\circ} \mathrm{C}$ for $30 \mathrm{~min}$. Subsequently, the second layer of $\mathrm{TiO}_{2}-\mathrm{NaYF}_{4}: \mathrm{Er}^{3+} / \mathrm{Yb}^{3+}-\mathrm{C}_{3} \mathrm{~N}_{4}$ was covered on the first $\mathrm{TiO}_{2}-\mathrm{NaYF}_{4}: \mathrm{Er}^{3+} / \mathrm{Yb}^{3+}-\mathrm{C}_{3} \mathrm{~N}_{4}$ film and then sintered at $450^{\circ} \mathrm{C}$ for $30 \mathrm{~min}$ again. The sensitization of the photoelectrodes was achieved by immersing them into $0.5 \mathrm{mmol}$ $\mathrm{L}^{-1} \quad\left(\left(\mathrm{C}_{4} \mathrm{H}_{9}\right)_{4} \mathrm{~N}\right)_{2}[\mathrm{Ru}(4$-carboxy-4'-carboxylate-2,2' bipyridine $)_{2}(\mathrm{NCS})_{2}$ ] dye (N719, Solaronix SA, Switzerland) in acetonitrile and tert-butanol (volume ratio, 1:1) for $48 \mathrm{~h}$ at room temperature. The Pt counter electrodes were prepared following the previous literature [32]. The dye-sensitized photoanode was assembled with a Pt counter electrode into a sandwich-type cell. The sandwich-type cell was further fixed together with epoxy resin. The space between the electrodes was filled with the electrolyte, which comprised $0.6 \mathrm{~mol} \mathrm{~L}^{-1} 1$-propyl-2,3-dimethyl-imidazolium iodide, $0.05 \mathrm{~mol} \mathrm{~L}^{-1} \mathrm{I}_{2}, 0.1 \mathrm{~mol} \mathrm{~L}^{-1} \mathrm{LiI}$, and 0.5 mol $\mathrm{L}^{-1}$ tert-butylpyridine (TBP) in 3-methoxypropionitrile (3-MPN), by capillary action.

\section{Photovoltaic properties}

Photovoltaic measurements were carried out with a solar simulator (Oriel, USA) equipped with an AM 1.5G radiation (one sun conditions, $100 \mathrm{~mW} \mathrm{~cm}{ }^{-2}$ ) filter as the light source. The irradiation area of DSSCs was $0.09 \mathrm{~cm}^{2}$. The EIS were performed with a computer-controlled IM6 impedance measurement unit (Zahner Elektrik, Germany) and carried out by applying sinusoidal perturbations of $10 \mathrm{mV}$ with a bias of $-0.8 \mathrm{~V}$ at a frequency ranging from $10 \mathrm{mHz}$ to $1 \mathrm{MHz}$. The obtained spectra were fitted with ZsimpWin software in terms of appropriate equivalent circuits. The electron transport and recombination properties were measured by intensity-modulated photocurrent spectroscopy (IMPS) and intensity-modulated photovoltage spectroscopy (IMVS) (Zahner Elektrik, Germany). The DSSCs were probed through the photoanode side by a frequency response analyzer using a white light emitting diode (wlr-01) as the light source. The frequency range was $0.1-1000 \mathrm{~Hz}$. The irradiated intensity was varied from 30 to $150 \mathrm{~W} \mathrm{~m}^{-2}$.

\section{RESULTS AND DISCUSSION}

\section{Crystal structures and morphologies of samples}

The crystal structure, particle size and morphologies of the products were obtained by XRD, TEM and SEM images. Fig. 1 shows the XRD patterns for the prepared $\mathrm{NaYF}_{4}: \mathrm{Er}^{3+} / \mathrm{Yb}^{3+}, \mathrm{g}-\mathrm{C}_{3} \mathrm{~N}_{4}$, and $\mathrm{NaYF}_{4}: \mathrm{Er}^{3+} / \mathrm{Yb}^{3+}-\mathrm{C}_{3} \mathrm{~N}_{4}$ nanocomposites. As shown in curve 1 of Fig. 1a, the positions of the diffraction peaks for the pure $\mathrm{NaYF}_{4}: \mathrm{Er}^{3+} / \mathrm{Yb}^{3+}$ 

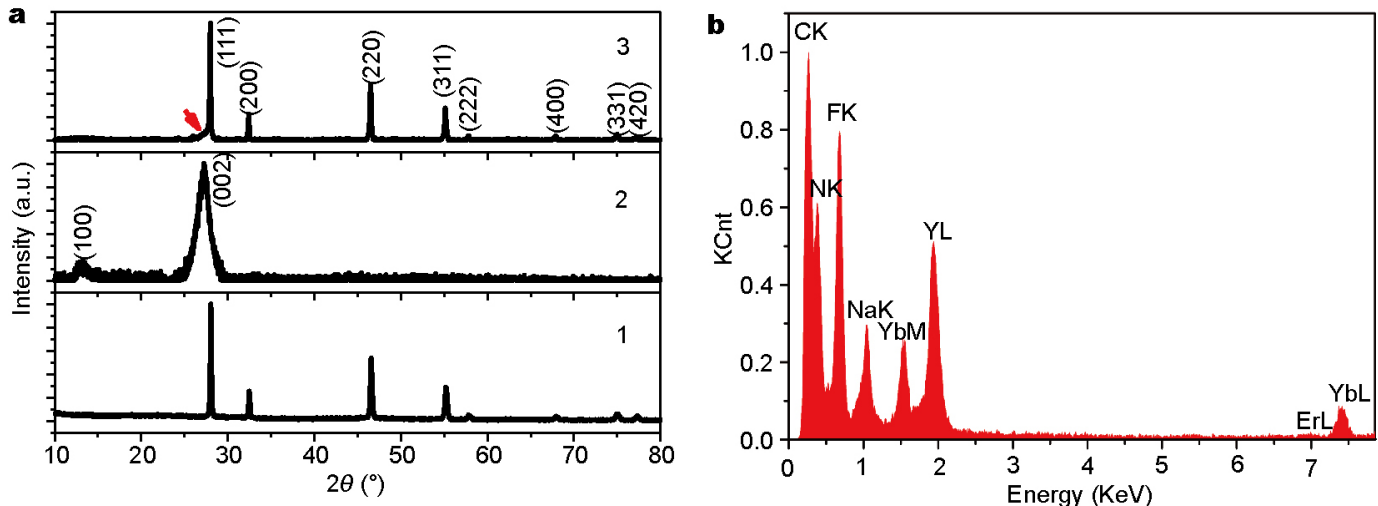

Figure 1 (a) XRD patterns of (1) $\mathrm{NaYF}_{4}: \mathrm{Er}^{3+} / \mathrm{Yb}^{3+}$, (2) $\mathrm{C}_{3} \mathrm{~N}_{4}$, (3) $\mathrm{NaYF}_{4}: \mathrm{Er}^{3+} / \mathrm{Yb}^{3+}-\mathrm{C}_{3} \mathrm{~N}_{4}$ nanocomposites, and (b) $\mathrm{EDX}$ analysis of the $\mathrm{NaYF}_{4}: \mathrm{Er}^{3+} / \mathrm{Yb}^{3+}-$ $\mathrm{C}_{3} \mathrm{~N}_{4}$ nanocomposites.

nanocrystals could be easily indexed as a pure cubic phase $\mathrm{NaYF}_{4}: \mathrm{Er}^{3+} / \mathrm{Yb}^{3+}$ (JCPDS No. 39-0724). No other impurity peaks were detected. Curve 2 in Fig. 1a shows the XRD pattern of $\mathrm{g}-\mathrm{C}_{3} \mathrm{~N}_{4}$. The pure $\mathrm{g}-\mathrm{C}_{3} \mathrm{~N}_{4}$ sample has distinct peaks at $13.0^{\circ}$ and $27.3^{\circ}$, which were indexed as (100) and (002) diffraction planes. Curve 3 in Fig. 1a shows the XRD pattern of the $\mathrm{NaYF}_{4}: \mathrm{Er}^{3+} / \mathrm{Yb}^{3+}-\mathrm{C}_{3} \mathrm{~N}_{4}$ nanocomposites. The results indicated that $\mathrm{NaYF}_{4}: \mathrm{Er}^{3+} / \mathrm{Yb}^{3+}$ and $\mathrm{C}_{3} \mathrm{~N}_{4}$ coexisted in the $\mathrm{NaYF}_{4}: \mathrm{Er}^{3+} / \mathrm{Yb}^{3+}-\mathrm{C}_{3} \mathrm{~N}_{4}$ nanocomposites. The crystal phase of $\mathrm{NaYF}_{4}: \mathrm{Er}^{3+} / \mathrm{Yb}^{3+}$ remained unchanged after compositing with $\mathrm{g}-\mathrm{C}_{3} \mathrm{~N}_{4}$. In order to further investigate the $\mathrm{NaYF}_{4}: \mathrm{Er}^{3+} / \mathrm{Yb}^{3+}-\mathrm{C}_{3} \mathrm{~N}_{4}$ nanocomposites, we measured the compositions by using energy dispersive $\mathrm{X}$-ray analysis
(EDX), as shown in Fig. 1b. The results indicated that the elemental components were $\mathrm{C}, \mathrm{N}, \mathrm{Na}, \mathrm{F}, \mathrm{Y}, \mathrm{Yb}$ and $\mathrm{Er}$, indicating that the $\mathrm{NaYF}_{4}: \mathrm{Er}^{3+} / \mathrm{Yb}^{3+}$ and $\mathrm{C}_{3} \mathrm{~N}_{4}$ coexisted in the nanocomposites.

The TEM image of $\mathrm{C}_{3} \mathrm{~N}_{4}$ is shown in Fig. 2a. Obviously, $\mathrm{C}_{3} \mathrm{~N}_{4}$ exhibits a sheet like morphology. The corresponding TEM images of $\mathrm{NaYF}_{4}: \mathrm{Er}^{3+} / \mathrm{Yb}^{3+}$ and $\mathrm{NaYF}_{4}: \mathrm{Er}^{3+} / \mathrm{Yb}^{3+}-\mathrm{C}_{3} \mathrm{~N}_{4}$ nanocomposites are shown in Fig. 2b-f. The results of TEM images indicated that the $\mathrm{NaYF}_{4}: \mathrm{Er}^{3+} / \mathrm{Yb}^{3+}$ nanocrystals tended to aggregate. A large amount of $\mathrm{NaYF}_{4}: \mathrm{Er}^{3+} / \mathrm{Yb}^{3+}$ nanocrystals were on the surface of $\mathrm{C}_{3} \mathrm{~N}_{4}$ sheets.

Fig. 3a shows the FTIR spectra of $\mathrm{C}_{3} \mathrm{~N}_{4}, \mathrm{NaYF}_{4}: \mathrm{Er}^{3+} / \mathrm{Yb}^{3+}$,
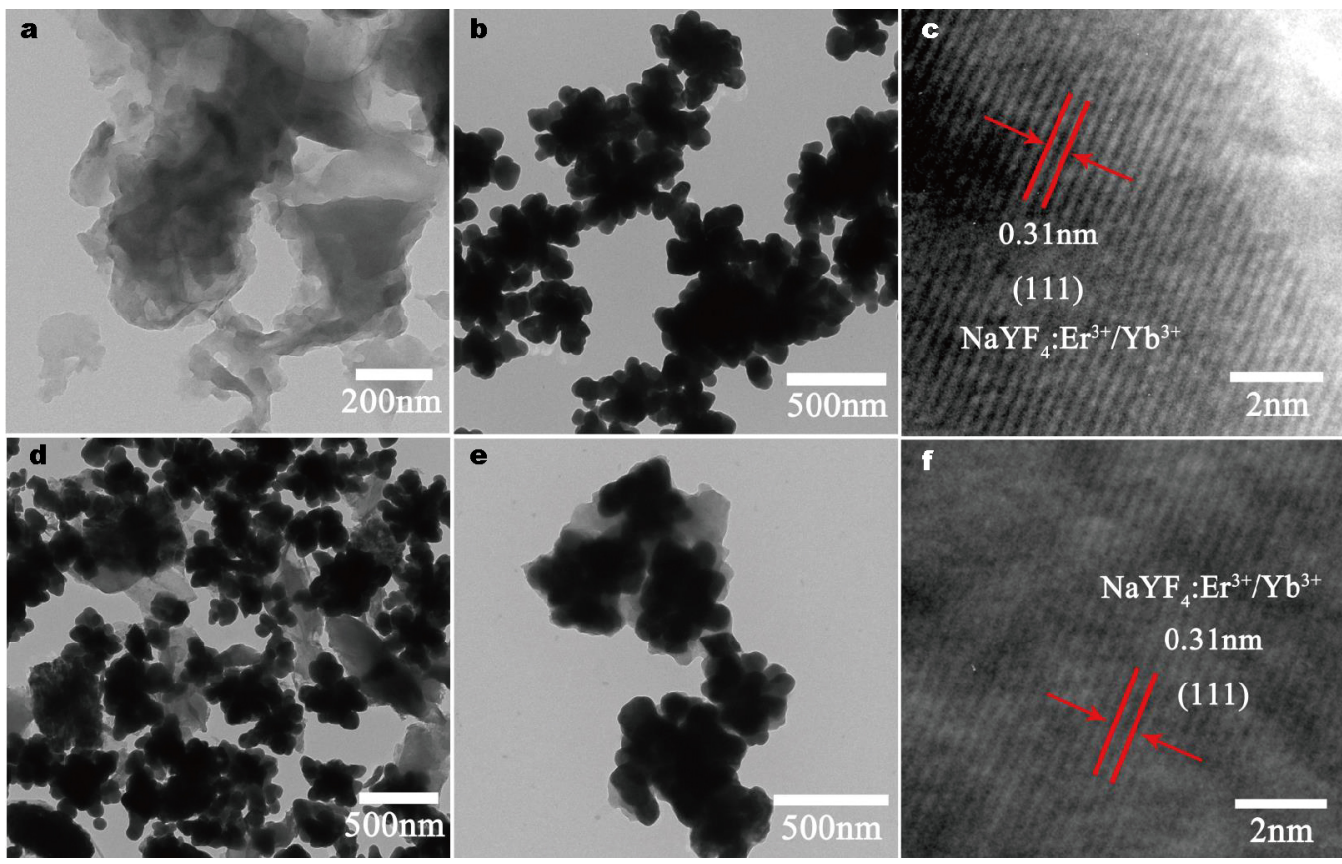

Figure 2 The TEM and HRTEM images of (a) $\mathrm{C}_{3} \mathrm{~N}_{4},(b, c) \mathrm{NaYF}_{4}: \mathrm{Er}^{3+} / \mathrm{Yb}^{3+}$, and (d-f) $\mathrm{NaYF}_{4}: \mathrm{Er}^{3+} / \mathrm{Yb}^{3+}-\mathrm{C}_{3} \mathrm{~N}_{4}$ nanocomposites. 
and $\mathrm{NaYF}_{4}: \mathrm{Er}^{3+} / \mathrm{Yb}^{3+}-\mathrm{C}_{3} \mathrm{~N}_{4}$ nanocomposites. The peaks at 1638 and $1238 \mathrm{~cm}^{-1}$ were attributed to the $\mathrm{C}=\mathrm{N}$ and $\mathrm{C}-\mathrm{N}$ stretching vibrations, respectively. It is noted that the $\mathrm{C}=\mathrm{N}$ and $\mathrm{C}-\mathrm{N}$ stretching vibration peaks moved to a higher wavenumber after compositing with $\mathrm{NaYF}_{4}: \mathrm{Er}^{3+} / \mathrm{Yb}^{3+}$, suggesting the formation of $\mathrm{NaYF}_{4}: \mathrm{Er}^{3+} / \mathrm{Yb}^{3+}-\mathrm{C}_{3} \mathrm{~N}_{4}$ nanocomposites. The amount of $\mathrm{C}_{3} \mathrm{~N}_{4}$ could be obtained by thermogravimetric analysis (TGA), as shown in Fig. 3b. The amount of $\mathrm{C}_{3} \mathrm{~N}_{4}$ in all $\mathrm{NaYF}_{4}: \mathrm{Er}^{3+} / \mathrm{Yb}^{3+}-\mathrm{C}_{3} \mathrm{~N}_{4}$ nanocomposites could be calculated from the second weight loss, and the results indicated that the amount of $\mathrm{C}_{3} \mathrm{~N}_{4}$ was nearly consistent to the dosage of $\mathrm{C}_{3} \mathrm{~N}_{4}$ added.

The optical absorption of the $\mathrm{NaYF}_{4}: \mathrm{Er}^{3+} / \mathrm{Yb}^{3+}, \mathrm{C}_{3} \mathrm{~N}_{4}$ and $\mathrm{NaYF}_{4}: \mathrm{Er}^{3+} / \mathrm{Yb}^{3+}-\mathrm{C}_{3} \mathrm{~N}_{4}$ nanocomposites was conducted with a UV-vis absorption spectrometer, as shown in Fig. 4a. The UV-vis absorption band increases with increasing the amount of $\mathrm{C}_{3} \mathrm{~N}_{4}$, which is benefit for the absorption of excitation light.

It is well known that the photoelectric performance of DSSCs was closely related to the specific surface areas of the samples. $\mathrm{N}_{2}$ adsorption-desorption isotherms of the as-obtained $\mathrm{C}_{3} \mathrm{~N}_{4}$ and $\mathrm{NaYF}_{4}: \mathrm{Er}^{3+} / \mathrm{Yb}^{3+}-\mathrm{C}_{3} \mathrm{~N}_{4}$ nanocomposites with different $\mathrm{C}_{3} \mathrm{~N}_{4}$ contents were performed to determine the surface area of the samples, as shown in Fig. 4b. The Brunauer-Emmett-Teller (BET) surface areas are 6.1291, 7.1199, and 9.2241 m² $\mathrm{g}^{-1}$ for $\mathrm{NaYF}_{4}: \mathrm{Er}^{3+} / \mathrm{Yb}^{3+}-\mathrm{C}_{3} \mathrm{~N}_{4}$ (1:0.25), $\mathrm{NaYF}_{4}: \mathrm{Er}^{3+} / \mathrm{Yb}^{3+}-\mathrm{C}_{3} \mathrm{~N}_{4}$ (1:0.5), and $\mathrm{C}_{3} \mathrm{~N}_{4}$, respectively.

\section{UC luminescence of $\mathrm{NaYF}_{4}: \mathrm{Er}^{3+} / \mathrm{Yb}^{3+}$ and $\mathrm{NaYF}_{4}: \mathrm{Er}^{3+} / \mathrm{Yb}^{3+}-\mathrm{C}_{3} \mathrm{~N}_{4}$}

The UC luminescent spectra of the cubic phase $\mathrm{NaYF}_{4}: \mathrm{Er}^{3+} / \mathrm{Yb}^{3+}$ and $\mathrm{NaYF}_{4}: \mathrm{Er}^{3+} / \mathrm{Yb}^{3+}-\mathrm{C}_{3} \mathrm{~N}_{4}$ were measured, as shown in Fig. 5. The emissions centered at 379, $409,520,539$, and $651 \mathrm{~nm}$ originated from the ${ }^{4} \mathrm{G}_{11 / 2} \rightarrow{ }^{4} \mathrm{I}_{15 / 2}$, ${ }^{2} \mathrm{H}_{9 / 2} \rightarrow{ }^{4} \mathrm{I}_{15 / 2},{ }^{2} \mathrm{H}_{11 / 2} \rightarrow{ }^{4} \mathrm{I}_{15 / 2},{ }^{4} \mathrm{~S}_{3 / 2} \rightarrow{ }^{4} \mathrm{I}_{15 / 2}$, and ${ }^{4} \mathrm{~F}_{9 / 2} \rightarrow{ }^{4} \mathrm{I}_{15 / 2}$ of $\mathrm{Er}^{3+}$ ions, respectively. For comparison, the absorption spectrum of $\mathrm{NaYF}_{4}: \mathrm{Er}^{3+} / \mathrm{Yb}^{3+}-\mathrm{C}_{3} \mathrm{~N}_{4}$ was also shown in Fig. 5. We can find the absorption band of $\mathrm{C}_{3} \mathrm{~N}_{4}$ overlaps very well with the 379 and $409 \mathrm{~nm}$ emission peaks of $\mathrm{NaYF}_{4}: \mathrm{Er}^{3+}$ /
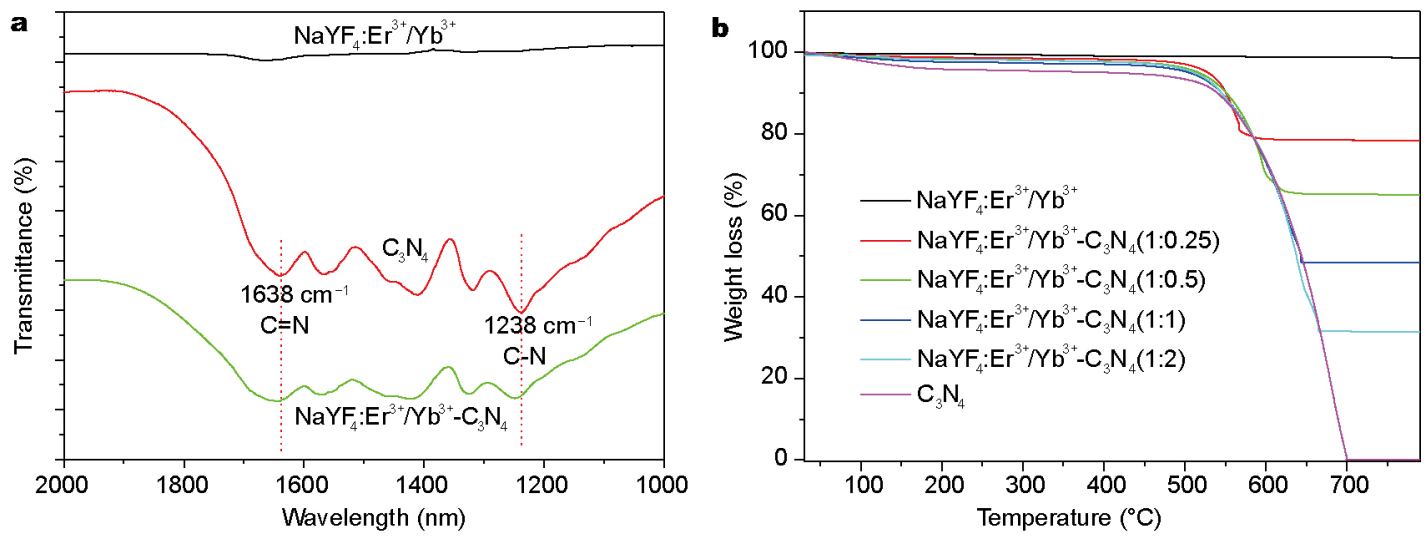

Figure 3 (a) FT-IR spectra and (b) TGA curves of $\mathrm{NaYF}_{4}: \mathrm{Er}^{3+} / \mathrm{Yb}^{3+}, \mathrm{C}_{3} \mathrm{~N}_{4}$ and $\mathrm{NaYF}_{4}: \mathrm{Er}^{3+} / \mathrm{Yb}^{3+}-\mathrm{C}_{3} \mathrm{~N}_{4}$ nanocomposites.
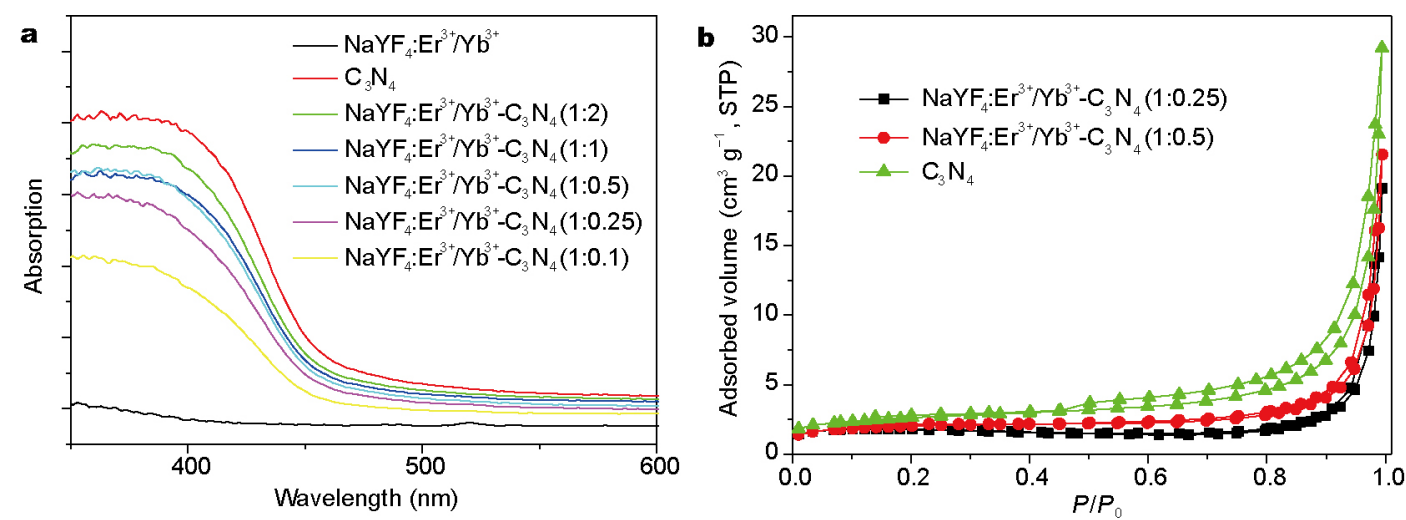

Figure 4 (a) UV-vis absorption spectra and (b) $\mathrm{N}_{2}$ adsorption-desorption isotherm curves of $\mathrm{NaYF}_{4}: \mathrm{Er}^{3+} / \mathrm{Yb}^{3+}, \mathrm{C}_{3} \mathrm{~N}_{4}$, and $\mathrm{NaYF}_{4}: \mathrm{Er}^{3+} / \mathrm{Yb}^{3+}-\mathrm{C}_{3} \mathrm{~N}_{4}$ nanocomposites. 


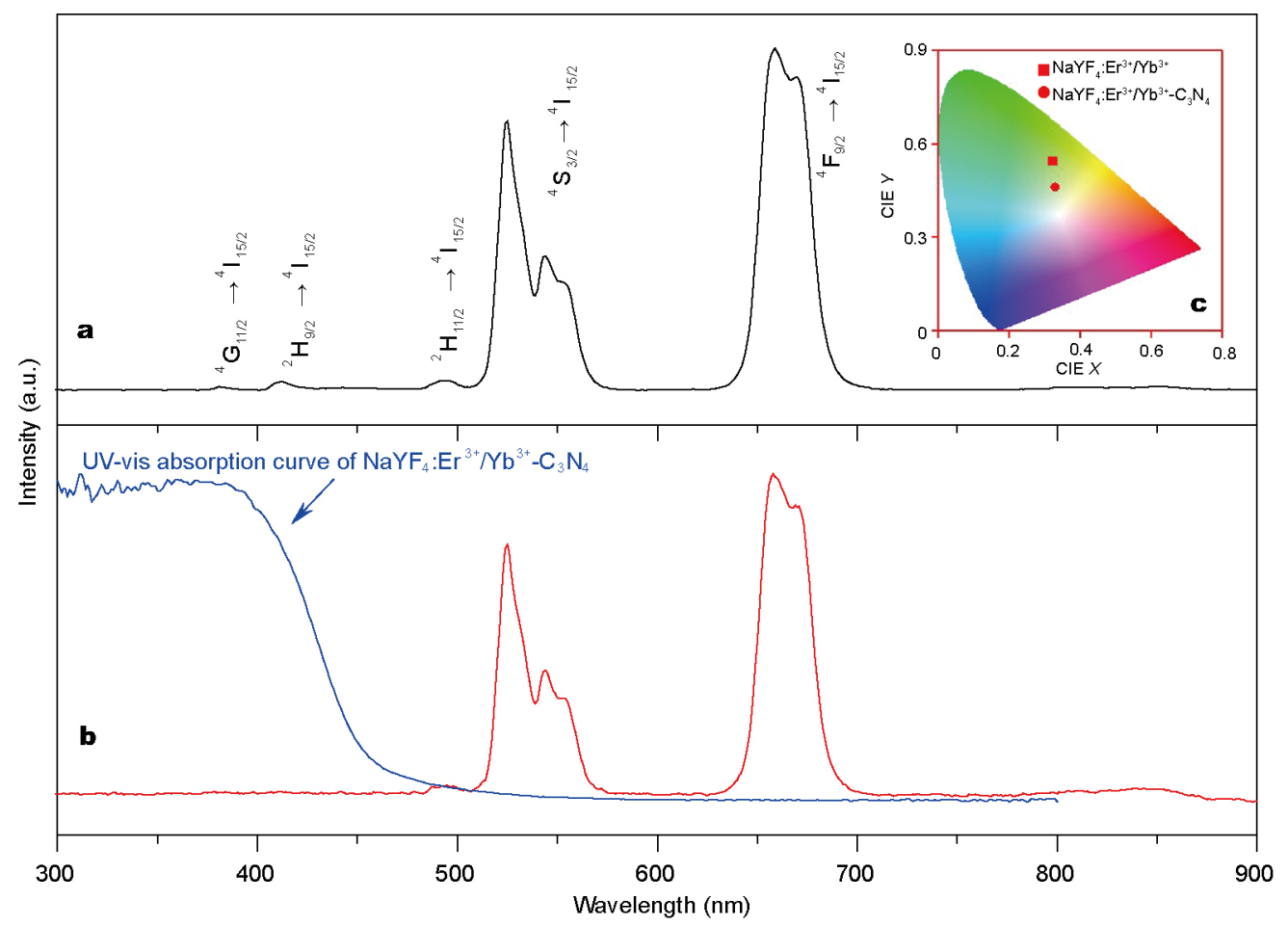

Figure 5 UC luminescence spectra of (a) $\mathrm{NaYF}_{4}: \mathrm{Er}^{3+} / \mathrm{Yb}^{3+}$ (black curve) and (b) $\mathrm{NaYF}_{4}: \mathrm{Er}^{3+} / \mathrm{Yb}^{3+}-\mathrm{C}_{3} \mathrm{~N}_{4}$ (red curve) under $980 \mathrm{~nm}$ excitation. The blue curve shows the absorption spectrum of $\mathrm{NaYF}_{4}: \mathrm{Er}^{3+} / \mathrm{Yb}^{3+}-\mathrm{C}_{3} \mathrm{~N}_{4}$. (c) CIE diagram of $\mathrm{NaYF}_{4}: \mathrm{Er}^{3+} / \mathrm{Yb}^{3+}$ and $\mathrm{NaYF}_{4}: \mathrm{Er}^{3+} / \mathrm{Yb}^{3+}-\mathrm{C}_{3} \mathrm{~N}_{4}$ nanocomposites.

$\mathrm{Yb}^{3+}$ nanocrystals. And thus, the 379 and $409 \mathrm{~nm}$ emission can be highly quenched due to being absorbed of $\mathrm{C}_{3} \mathrm{~N}_{4}$. As expected, the ${ }^{4} \mathrm{G}_{11 / 2} \rightarrow{ }^{4} \mathrm{I}_{15 / 2}$ and ${ }^{2} \mathrm{H}_{9 / 2} \rightarrow{ }^{4} \mathrm{I}_{15 / 2}$ emissions of $\mathrm{NaYF}_{4}: \mathrm{Er}^{3+} / \mathrm{Yb}^{3+}-\mathrm{C}_{3} \mathrm{~N}_{4}$ almost disappeared. The CIE coordinates of the UC luminescence were $(0.322$, $0.545)$ and $(0.327,0.462)$ for the $\mathrm{NaYF}_{4}: \mathrm{Er}^{3+} / \mathrm{Yb}^{3+}$ and $\mathrm{NaYF}_{4}: \mathrm{Er}^{3+} / \mathrm{Yb}^{3+}-\mathrm{C}_{3} \mathrm{~N}_{4}$, respectively.

To investigate the fundamental UC mechanism of $\mathrm{NaYF}_{4}: \mathrm{Er}^{3+} / \mathrm{Yb}^{3+}-\mathrm{C}_{3} \mathrm{~N}_{4}$, the pumping power dependence of the fluorescent intensity was investigated. Fig. 6 shows the logarithmic plots of the emission intensity as a function of excitation power for the ${ }^{4} \mathrm{~F}_{7 / 2} /{ }^{2} \mathrm{H}_{11 / 2} /{ }^{4} S_{3 / 2} \rightarrow{ }^{4} \mathrm{I}_{15 / 2}$ and ${ }^{4} \mathrm{~F}_{9 / 2} \rightarrow{ }^{4} \mathrm{I}_{15 / 2}$ emissions. For an unsaturated UC process, the emission intensity is proportional to the $n^{\text {th }}$ power of the excitation intensity, and the integer $n$ is the number of the laser photons absorbed per upconverted photon emitted. Obviously, the values of $n$ for $\mathrm{NaYF}_{4}: \mathrm{Er}^{3+} / \mathrm{Yb}^{3+}-\mathrm{C}_{3} \mathrm{~N}_{4}$ nanocomposites are smaller than those for $\mathrm{NaYF}_{4}: \mathrm{Er}^{3+} / \mathrm{Yb}^{3+}$, which can be attributed to the energy transfer from $\mathrm{NaYF}_{4}: \mathrm{Er}^{3+} / \mathrm{Yb}^{3+}$ to $\mathrm{C}_{3} \mathrm{~N}_{4}$.
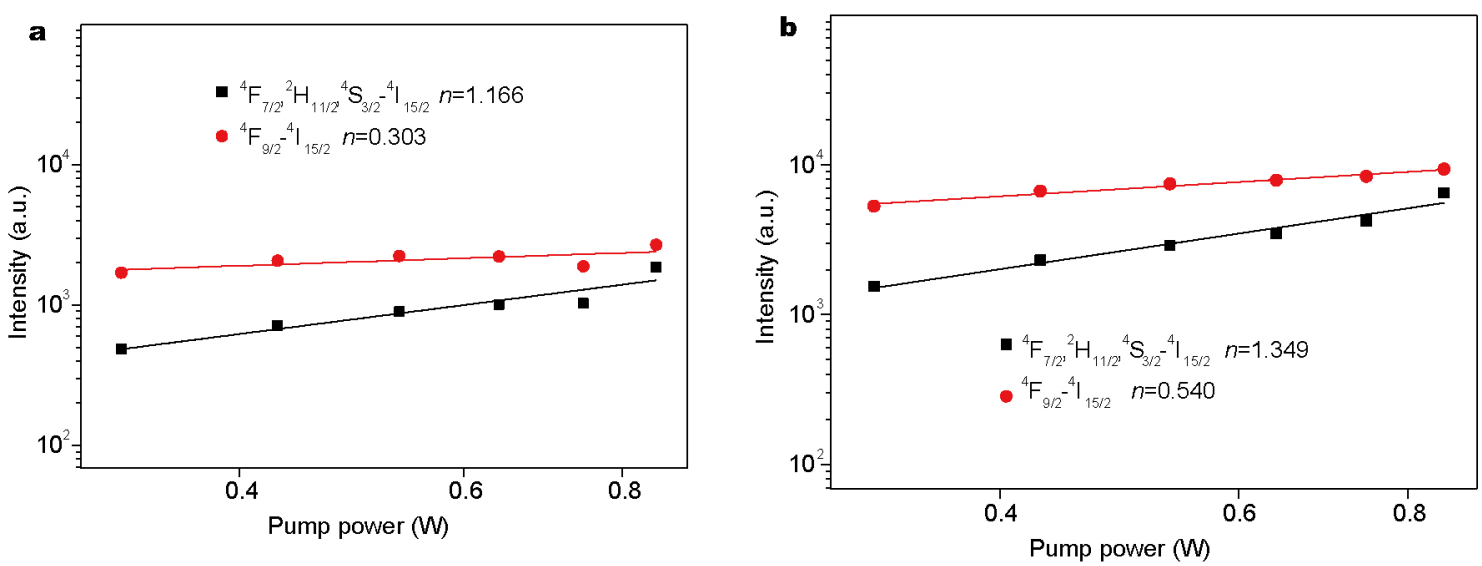

Figure 6 Plots (log-log) of emission intensity versus excitation power in (a) $\mathrm{NaYF}_{4}: \mathrm{Er}^{3+} / \mathrm{Yb}^{3+}-\mathrm{C}_{3} \mathrm{~N}_{4}$ and (b) $\mathrm{NaYF}_{4}: \mathrm{Er}^{3+} / \mathrm{Yb}^{3+}$. 
Fig. S1 in Supplementary information shows the emission spectrum of the $\mathrm{NaYF}_{4}: \mathrm{Er}^{3+} / \mathrm{Yb}^{3+}$ excited at 495 nm. The ${ }^{2} \mathrm{H}_{11 / 2} \rightarrow{ }^{4} \mathrm{I}_{15 / 2}$ and ${ }^{4} \mathrm{~S}_{3 / 2} \rightarrow{ }^{4} \mathrm{I}_{15 / 2}$ transitions were observed. Figs $\mathrm{S} 2$ and $\mathrm{S} 3$ show the excitation spectra of the $\mathrm{NaYF}_{4}: \mathrm{Er}^{3+} / \mathrm{Yb}^{3+}$ monitored at 522 and $550 \mathrm{~nm}$, respectively.

\section{Photoelectrochemical properties of $\mathrm{TiO}_{2}-\mathrm{NaYF}_{4}: \mathrm{Er}^{3+} / \mathrm{Yb}^{3+}-$ $\mathrm{C}_{3} \mathrm{~N}_{4}$ composite DSSCs}

In order to investigate the effects of $\mathrm{NaYF}_{4}: \mathrm{Er}^{3+} / \mathrm{Yb}^{3+}-\mathrm{C}_{3} \mathrm{~N}_{4}$ on the photoelectric properties of DSSCs, the DSSC prototype devices were fabricated using N719-sensitised $\mathrm{TiO}_{2}$ $\mathrm{NaYF}_{4}: \mathrm{Er}^{3+} / \mathrm{Yb}^{3+}-\mathrm{C}_{3} \mathrm{~N}_{4}$ composite as electrodes. Here, the mass ratio of $\mathrm{NaYF}_{4}: \mathrm{Er}^{3+} / \mathrm{Yb}^{3+}: \mathrm{C}_{3} \mathrm{~N}_{4}$ was 1:2. Fig. 7a shows the photocurrent density-voltage $(J-V)$ curves of pure $\mathrm{TiO}_{2}$, $\mathrm{TiO}_{2}-\mathrm{C}_{3} \mathrm{~N}_{4}$, and $\mathrm{TiO}_{2}-\mathrm{NaYF}_{4}: \mathrm{Er}^{3+} / \mathrm{Yb}^{3+}-\mathrm{C}_{3} \mathrm{~N}_{4}$ cells. The corresponding values of the open-circuit voltage $\left(V_{\mathrm{oc}}\right)$, shortcircuit current density $\left(J_{\text {sc }}\right)$, fill factor $(\mathrm{FF})$, and overall conversion efficiency $(\eta)$, obtained from the curves of solar cells, are shown in Table 1. It was found that the performance of $\mathrm{TiO}_{2}-\mathrm{NaYF}_{4}: \mathrm{Er}^{3+} / \mathrm{Yb}^{3+}-\mathrm{C}_{3} \mathrm{~N}_{4}$ cell was not only higher than that of pure $\mathrm{TiO}_{2}$ cell, but also higher than those of $\mathrm{TiO}_{2}-\mathrm{C}_{3} \mathrm{~N}_{4}$ cell. It is noted that the photoelectric conversion efficiencies of the DSSCs were also enhanced by the incorporation of $\mathrm{NaYF}_{4}: \mathrm{Er}^{3+} / \mathrm{Yb}^{3+}-\mathrm{C}_{3} \mathrm{~N}_{4}$ with different mass ratio of $\mathrm{NaYF}_{4}: \mathrm{Er}^{3+} / \mathrm{Yb}^{3+}: \mathrm{C}_{3} \mathrm{~N}_{4}$. Detailed information on the light harvesting of the DSSCs can be ob-

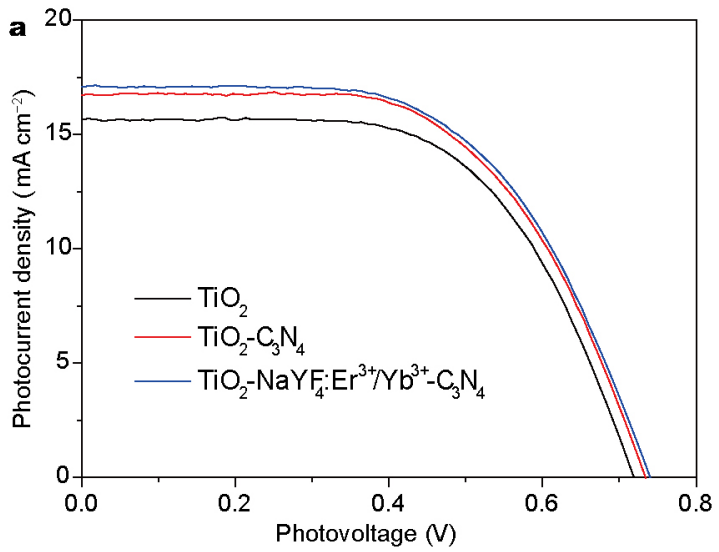

tained from the incident-photon-to-current conversion efficiency (IPCE) spectra in Fig. 7b. Obviously, the photoelectric conversion efficiency of the $\mathrm{TiO}_{2}-\mathrm{NaYF}_{4}: \mathrm{Er}^{3+} / \mathrm{Yb}^{3+}-$ $\mathrm{C}_{3} \mathrm{~N}_{4}$ cell was higher than that of pure $\mathrm{TiO}_{2}$ cell.

Presumably, several mechanisms might be responsible for the enhancement of the efficiency of the $\mathrm{TiO}_{2}$ $\mathrm{NaYF}_{4}: \mathrm{Er}^{3+} / \mathrm{Yb}^{3+}-\mathrm{C}_{3} \mathrm{~N}_{4}$ composite cell. First, the improvement of the efficiency of the $\mathrm{TiO}_{2}-\mathrm{NaYF}_{4}: \mathrm{Er}^{3+} / \mathrm{Yb}^{3+}-\mathrm{C}_{3} \mathrm{~N}_{4}$ composite cell was related to the luminescence of $\mathrm{NaYF}_{4}: \mathrm{Er}^{3+} / \mathrm{Yb}^{3+}$. However, the results of the IPCE spectra indicate that the luminescence of $\mathrm{NaYF}_{4}: \mathrm{Er}^{3+} / \mathrm{Yb}^{3+}$ only has a little effect on the performance improvement. Second, it is well known that the conduction and valence bands of the $\mathrm{RE}$ ion modified $\mathrm{TiO}_{2}$ nanoparticles have higher potentials than those of unmodified $\mathrm{TiO}_{2}$ nanoparticles due to the participation of $\mathrm{RE}$ ions in the hybridization orbital of $\mathrm{TiO}_{2}$, which can reduce the probability of recombination of excited electrons and holes to increase the short-circuit current during the operation of the DSSCs. Finally, the UV-vis absorption band of $\mathrm{NaYF}_{4}: \mathrm{Er}^{3+} / \mathrm{Yb}^{3+}-\mathrm{C}_{3} \mathrm{~N}_{4}$ increases with increasing the amount of $\mathrm{C}_{3} \mathrm{~N}_{4}$, which is beneficial for the absorption of visible light (Fig. 4). More importantly, $\mathrm{C}_{3} \mathrm{~N}_{4}$ has more negative conduction band position than that of $\mathrm{TiO}_{2}$, which may effectively prevent the migration of electrons from $\mathrm{TiO}_{2}$ to the electrolyte. And thus, the $\mathrm{TiO}_{2}-\mathrm{NaYF}_{4}: \mathrm{Er}^{3+} / \mathrm{Yb}^{3+}-\mathrm{C}_{3} \mathrm{~N}_{4}$ cell performance was improved by introducing $\mathrm{NaYF}_{4}: \mathrm{Er}^{3+} / \mathrm{Yb}^{3+}-\mathrm{C}_{3} \mathrm{~N}_{4}$.

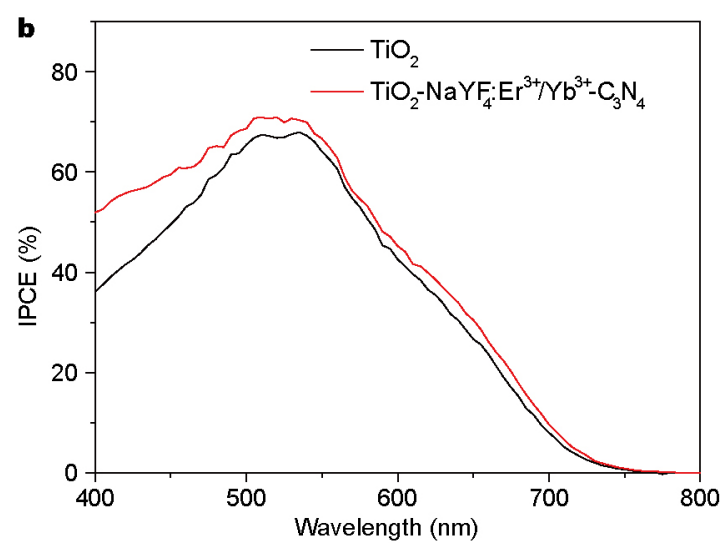

Figure 7 (a) $J-V$ curves of pure $\mathrm{TiO}_{2}, \mathrm{TiO}_{2}-\mathrm{C}_{3} \mathrm{~N}_{4}$, and $\mathrm{TiO}_{2}-\mathrm{NaYF}_{4}: \mathrm{Er}^{3+} / \mathrm{Yb}^{3+}-\mathrm{C}_{3} \mathrm{~N}_{4}$ cells. (b) IPCE of pure $\mathrm{TiO}_{2}$ and $\mathrm{TiO}_{2}-\mathrm{NaYF}_{4}: \mathrm{Er}^{3+} / \mathrm{Yb}^{3+}-\mathrm{C}_{3} \mathrm{~N}_{4}$ cells.

Table 1 Solar cell parameters of pure $\mathrm{TiO}_{2}$ cell, $\mathrm{TiO}_{2}-\mathrm{C}_{3} \mathrm{~N}_{4}$, and $\mathrm{TiO}_{2}-\mathrm{NaYF}_{4}: \mathrm{Er}^{3+} / \mathrm{Yb}^{3+}-\mathrm{C}_{3} \mathrm{~N}_{4}$ composite cells under simulated solar light radiation

\begin{tabular}{ccccc}
\hline DSSCs & $V_{\text {oc }}(\mathrm{V})$ & $J_{\text {sc }}\left(\mathrm{mA} \mathrm{cm}^{-2}\right)$ & FF & $\eta(\%)$ \\
\hline Pure $\mathrm{TiO}_{2}$ & 0.72 & 15.6 & 0.60 & 6.82 \\
$\mathrm{TiO}_{2}-\mathrm{C}_{3} \mathrm{~N}_{4}$ & 0.73 & 16.7 & 0.59 & 7.22 \\
$\mathrm{TiO}_{2}-\mathrm{NaYF}_{4}: \mathrm{Er}^{3+} / \mathrm{Yb}^{3+}-\mathrm{C}_{3} \mathrm{~N}_{4}$ & 0.74 & 17.1 & 0.58 & 7.37 \\
\hline
\end{tabular}


EIS is a powerful method to investigate internal resistances in the charge-transfer process of DSSCs. The wide frequency range of EIS means that it can measure wide-scale internal resistances of each electrochemical step at the same time. DSSCs are complex systems which are composed of several interfaces. A high level of electron accumulation must occur because photogenerated electrons are not extracted immediately at the electrode contact under illumination. Generally, the impedance at low frequency $(0.05-1 \mathrm{~Hz})$ refers to the Nernst diffusion of $\mathrm{I}_{3}^{-} / \mathrm{I}^{-}$within the electrolyte. The impedance at high frequency $(1-100 \mathrm{kHz})$ corresponds to the capacitance and charge-transfer resistance at the $\mathrm{Pt} \mid \mathrm{I}_{3}-/ \mathrm{I}^{-}$electrolyte interface. The medium-frequency response at $1-100 \mathrm{~Hz}$ is related to the photoelectrode-dye $\mid \mathrm{I}_{3}{ }^{-} / \mathrm{I}^{-}$electrolyte interface, where the accumulation of photoelectrons and redox shuttles is expected. Fig. 8a shows the EIS of pure $\mathrm{TiO}_{2}$ cell and $\mathrm{TiO}_{2}-\mathrm{NaYF}_{4}: \mathrm{Er}^{3+} / \mathrm{Yb}^{3+}-\mathrm{C}_{3} \mathrm{~N}_{4}$ cell. It can be seen that the interfacial resistance of the $\mathrm{TiO}_{2}$-dye $\mid \mathrm{I}_{3}{ }^{-} / \mathrm{I}^{-}$ electrolyte interface of $\mathrm{TiO}_{2}-\mathrm{NaYF}_{4}: \mathrm{Er}^{3+} / \mathrm{Yb}^{3+}-\mathrm{C}_{3} \mathrm{~N}_{4}$ cell is much smaller than that of pure $\mathrm{TiO}_{2}$ cell.
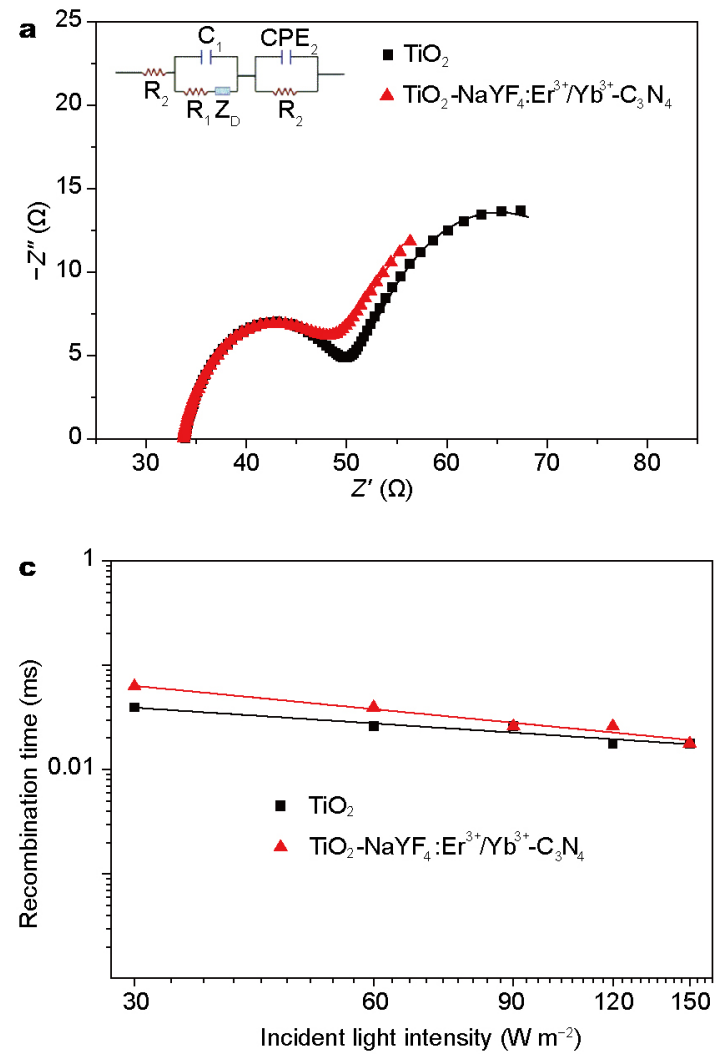

The inset of Fig. 8a shows the equivalent circuit fitting of the impedance spectra, $R_{\mathrm{s}}\left[C_{1}\left(R_{1} \mathrm{O}_{1}\right)\right]\left(R_{2} \mathrm{CPE}\right)$, which was used for all the DSSCs. $R_{\mathrm{s}}$ is the series resistance, corresponding to the sheet resistance of the FTO glass, the contact resistance and the wire resistance. $R_{2}$ represents the charge transfer resistance between the photoelectrodedye $\mid \mathrm{I}_{3}{ }^{-} / \mathrm{I}^{-}$electrolyte interface. $Z_{\text {Dif }}$ represents the finitelength Warburg impedance. The impedance of the finitelength Warburg diffusion is expressed as

$$
Z_{\text {Dif }}=R_{\text {Dif }} \frac{\tanh (j \varpi \tau)^{1 / 2}}{(j \varpi \tau)^{1 / 2}},
$$

where $R_{\text {Dif }}=B / Y_{0}$, and $\tau=B^{2} . B$ is a constant phase element. According to the equivalent circuit, the EIS data obtained by fitting the impedance spectra of composite DSSCs are listed in Table 2. It can be seen that $R_{2}$, representing the interfacial resistance of the $\mathrm{TiO}_{2}-$ dye $\mid \mathrm{I}_{3}{ }^{-} / \mathrm{I}^{-}$ electrolyte interface, is $10.27 \Omega$ for pure $\mathrm{TiO}_{2}$ cell and $8.473 \Omega$ for $\mathrm{TiO}_{2}-\mathrm{NaYF}_{4}: \mathrm{Er}^{3+} / \mathrm{Yb}^{3+}-\mathrm{C}_{3} \mathrm{~N}_{4}$ composite cell. In addition, the series resistance $\left(R_{\mathrm{s}}\right)$ for pure $\mathrm{TiO}_{2}$ cell and $\mathrm{TiO}_{2}-\mathrm{NaYF}_{4}: \mathrm{Er}^{3+} / \mathrm{Yb}^{3+}-\mathrm{C}_{3} \mathrm{~N}_{4}$ cell are 33.91 and $33.61 \Omega$,
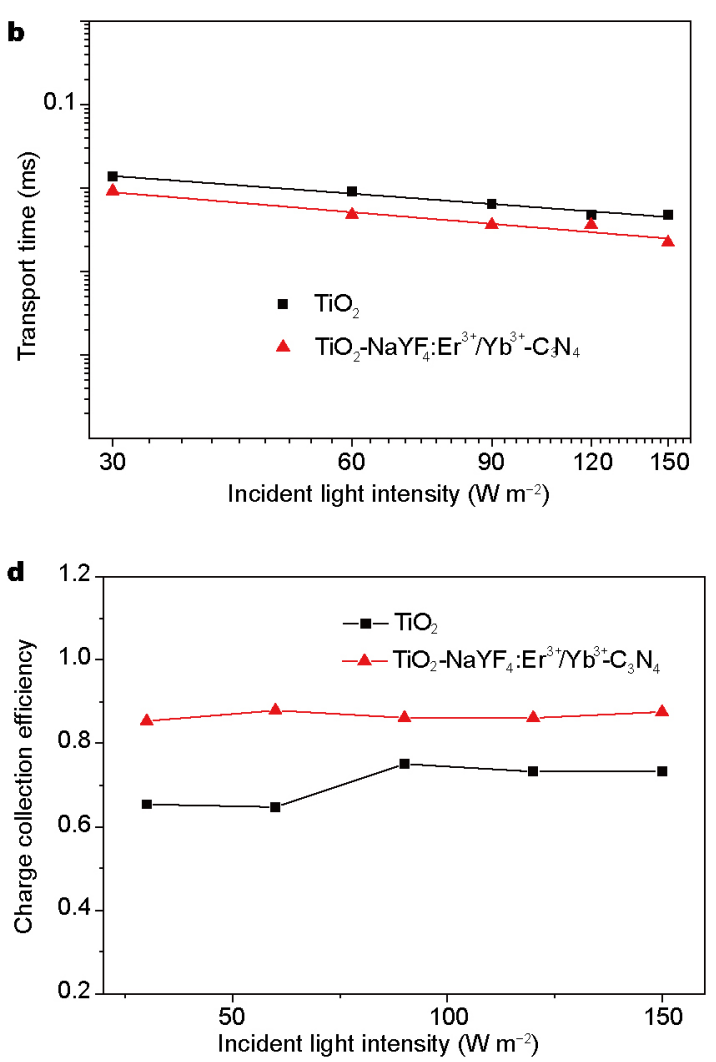

Figure 8 (a) Nyquist plots of DSSCs comprised of pure $\mathrm{TiO}_{2}$ cell and $\mathrm{TiO}_{2}-\mathrm{NaYF}_{4}: \mathrm{Er}^{3+} / \mathrm{Yb}^{3+}-\mathrm{C}_{3} \mathrm{~N}_{4}$ composite cell. (b) Transport time constant and (c) recombination time constant for DSSCs as a function of applied voltage (or quasi-Fermi energy). (d) Comparison of charge collection efficiency for DSSCs as a function of applied voltage (or quasi-Fermi energy). 
Table 2 Parameters obtained by fitting the impedance spectra of composite solar cells using the equivalent circuit in the inset in Fig. 8a

\begin{tabular}{cccccccc}
\hline DSSCs & $R_{\mathrm{s}}(\Omega)$ & $C_{1}(\mathrm{~F})$ & $R_{1}(\Omega)$ & $Y_{\mathrm{o} 1}(\mathrm{~S})$ & $B\left(\mathrm{~s}^{1 / 2}\right)$ & $R_{2}(\Omega)$ & $\mathrm{CPE}$ \\
\hline Pure $\mathrm{TiO}_{2}$ & 33.91 & $1.988 \times 10^{-5}$ & 2.299 & 0.006722 & 0.2179 & 10.27 & $1.546 \times 10^{-5}$ \\
$\mathrm{TiO}_{2}-\mathrm{NaYF}_{4}: \mathrm{Er}^{3+} / \mathrm{Yb}^{3+}-\mathrm{C}_{3} \mathrm{~N}_{4}$ & 33.61 & $2.575 \times 10^{-5}$ & 2.14 & 0.004464 & 0.4035 & 8.473 & $1.996 \times 10^{-5}$ \\
\hline
\end{tabular}

respectively, indicating that the incorporation of $\mathrm{NaYF}_{4}: \mathrm{Er}^{3+} / \mathrm{Yb}^{3+}-\mathrm{C}_{3} \mathrm{~N}_{4}$ is beneficial for the interfacial electron transfer of $\mathrm{FTO} \mid \mathrm{TiO}_{2}$.

In DSSCs, the electron recombination time $\left(\tau_{\mathrm{n}}\right)$, the electron transport time $\left(\tau_{\mathrm{d}}\right)$, and the charge collection efficiency $\left(\eta_{c c}\right)$ are important factors for the performance of DSSCs. IMPS and IMVS are conventional methods to investigate the electron transfer and recombination process. The IMPS response plots and IMVS response plots of pure $\mathrm{TiO}_{2}$ cell and $\mathrm{TiO}_{2}-\mathrm{NaYF}_{4}: \mathrm{Er}^{3+} / \mathrm{Yb}^{3+}-\mathrm{C}_{3} \mathrm{~N}_{4}$ composite cell are shown in Fig. 8b, c. Compared with pure $\mathrm{TiO}_{2}$ cell, the $\mathrm{TiO}_{2}-\mathrm{NaYF}_{4}: \mathrm{Er}^{3+} / \mathrm{Yb}^{3+}-\mathrm{C}_{3} \mathrm{~N}_{4}$ composite cell had longer electron recombination time and shorter electron transport time. It noted that shorter transport time and longer recombination time is beneficial for enhancing photoelectric properties.

The charge collection efficiencies $\left(\eta_{\mathrm{cc}}\right)$ of DSSCs are determined by the relation: $\eta_{\mathrm{cc}}=1-\tau_{\mathrm{d}} / \tau_{\mathrm{n}}$. Where, $\tau_{\mathrm{d}}$ is the charge transport time and $\tau_{\mathrm{n}}$ is the charge recombination lifetime. Fig. 8d shows the charge collection efficiencies of pure $\mathrm{TiO}_{2}$ cell and $\mathrm{TiO}_{2}-\mathrm{NaYF}_{4}: \mathrm{Er}^{3+} / \mathrm{Yb}^{3+}-\mathrm{C}_{3} \mathrm{~N}_{4}$ cell. The $\mathrm{TiO}_{2}-\mathrm{NaYF}_{4}: \mathrm{Er}^{3+} / \mathrm{Yb}^{3+}-\mathrm{C}_{3} \mathrm{~N}_{4}$ composite cell has a higher charge collection efficiency than pure $\mathrm{TiO}_{2}$ cell.

It is well known that the photoelectric conversion efficiencies of DSSCs are also related to the amount of dye adsorption on the $\mathrm{TiO}_{2}-\mathrm{NaYF}_{4}: \mathrm{Er}^{3+} / \mathrm{Yb}^{3+}$ photoanodes. Obviously, the amount of desorption dye of $\mathrm{TiO}_{2}-\mathrm{NaYF}_{4}: \mathrm{Er}^{3+} / \mathrm{Yb}^{3+}-\mathrm{C}_{3} \mathrm{~N}_{4}$ photoanode is larger than that of $\mathrm{TiO}_{2}-\mathrm{NaYF}_{4}: \mathrm{Er}^{3+} / \mathrm{Yb}^{3+}$ photoanode, as shown in the Fig. S4, which consistent with the result of BET surface areas (Fig. 4).

\section{CONCLUSIONS}

In summary, we successfully synthesized $\mathrm{NaYF}_{4}: \mathrm{Er}^{3+} / \mathrm{Yb}^{3+}$ $\mathrm{C}_{3} \mathrm{~N}_{4}$ nanocomposites by combining hydrothermal with chemisorption method, which not only exhibited enhanced bright UC luminescence under $980 \mathrm{~nm}$ excitation but also could be chosen to design $\mathrm{TiO}_{2}-\mathrm{NaYF}_{4}: \mathrm{Er}^{3+} / \mathrm{Yb}^{3+}-\mathrm{C}_{3} \mathrm{~N}_{4}$ composite photoanodes. The results indicated that the photoelectric conversion efficiency was enhanced greatly by the incorporation of $\mathrm{NaYF}_{4}: \mathrm{Er}^{3+} / \mathrm{Yb}^{3+}-\mathrm{C}_{3} \mathrm{~N}_{4}$. Especially, the photoelectric conversion efficiency of $\mathrm{TiO}_{2}-\mathrm{NaYF}_{4}: \mathrm{Er}^{3+} / \mathrm{Yb}^{3+}-\mathrm{C}_{3} \mathrm{~N}_{4}$ composite cell was also higher than that of $\mathrm{TiO}_{2}-\mathrm{C}_{3} \mathrm{~N}_{4}$ composite cell. The result of EIS analysis revealed that the interfacial resistance of the $\mathrm{TiO}_{2}$-dye $\mid \mathrm{I}_{3}^{-} / \mathrm{I}^{-}$electrolyte interface of $\mathrm{TiO}_{2}-\mathrm{NaYF}_{4}: \mathrm{Er}^{3+} / \mathrm{Yb}^{3+}-\mathrm{C}_{3} \mathrm{~N}_{4}$ composite cell was much smaller than that of pure $\mathrm{TiO}_{2}$ cell. In addition, the $\mathrm{TiO}_{2}-\mathrm{NaYF}_{4}: \mathrm{Er}^{3+} / \mathrm{Yb}^{3+}{ }_{-} \mathrm{C}_{3} \mathrm{~N}_{4}$ composite cell has longer electron recombination time and shorter electron transport time than that of pure $\mathrm{TiO}_{2}$ cell. Overall, the significantly improved photoelectric conversion efficiency of DSSC is ascribed to the synergetic effect of $\mathrm{NaYF}_{4}: \mathrm{Er}^{3+} / \mathrm{Yb}^{3+}$ and $\mathrm{C}_{3} \mathrm{~N}_{4}$.

Received 17 December 2016; accepted 24 January 2017; published online 20 February 2017

1 O'Regan B, Graetzel M. A low-cost, high-efficiency solar cell based on dye-sensitized colloidal $\mathrm{TiO}_{2}$ films. Nature, 1991, 353: 737-740

2 Sun Q, Li Y, Dou J, et al. Improving the efficiency of dye-sensitized solar cells by photoanode surface modifications. Sci China Mater, 2016, 59: 867-883

3 Li LB, Wu WQ, Rao HS, et al. Hierarchical ZnO nanorod-onnanosheet arrays electrodes for efficient CdSe quantum dot-sensitized solar cells. Sci China Mater, 2016, 59: 807-816

4 Ding Y, Xia X, Chen W, et al. Inside-out Ostwald ripening: a facile process towards synthesizing anatase $\mathrm{TiO}_{2}$ microspheres for highefficiency dye-sensitized solar cells. Nano Res, 2016, 9: 1891-1903

5 Kim S, Lee JK, Kang SO, et al. Molecular engineering of organic sensitizers for solar cell applications. J Am Chem Soc, 2006, 128: 16701-16707

6 Wang M, Chamberland N, Breau L, et al. An organic redox electrolyte to rival triiodide/iodide in dye-sensitized solar cells. Nat Chem, 2010, 2: 385-389

7 Thapa A, Zai J, Elbohy $\mathrm{H}$, et al. $\mathrm{TiO}_{2}$ coated urchin-like $\mathrm{SnO}_{2}$ microspheres for efficient dye-sensitized solar cells. Nano Res, 2014, 7: 1154-1163

8 Yoo D, Kim J, Kim JH. Direct synthesis of highly conductive poly(3,4-ethylenedioxythiophene):poly(4-styrenesulfonate) (PEDOT:PSS)/graphene composites and their applications in energy harvesting systems. Nano Res, 2014, 7: 717-730

9 Mathew S, Yella A, Gao P, et al. Dye-sensitized solar cells with $13 \%$ efficiency achieved through the molecular engineering of porphyrin sensitizers. Nat Chem, 2014, 6: 242-247

10 Yu M, Su J, Wang G, et al. $\mathrm{Pt} / \mathrm{Y}_{2} \mathrm{O}_{3}: \mathrm{Eu}^{3+}$ composite nanotubes: enhanced photoluminescence and application in dye-sensitized solar cells. Nano Res, 2016, 9: 2338-2346

11 Zhang Y, Zhang B, Peng X, et al. Preparation of dye-sensitized solar cells with high photocurrent and photovoltage by using mesoporous titanium dioxide particles as photoanode material. Nano Res, 2015, 8: 3830-3841

12 Zhang J, Li S, Yang $\mathrm{P}$, et al. Deposition of transparent $\mathrm{TiO}_{2}$ nanotubes-films via electrophoretic technique for photovoltaic applications. Sci China Mater, 2015, 58: 785-790 
13 Shen $\mathrm{T}$, Tian J, Li B, et al. Ultrathin ALD coating on $\mathrm{TiO}_{2}$ photoanodes with enhanced quantum dot loading and charge collection in quantum dots sensitized solar cells. Sci China Mater, 2016, 59: 833-841

14 Wang G, Peng Q, Li Y. Lanthanide-doped nanocrystals: synthesis, optical-magnetic properties, and applications. Acc Chem Res, 2011, 44: 322-332

15 Yu W, Xu W, Song H, et al. Temperature-dependent upconversion luminescence and dynamics of $\mathrm{NaYF}_{4}: \mathrm{Yb}^{3+} / \mathrm{Er}^{3+}$ nanocrystals: influence of particle size and crystalline phase. Dalton Trans, 2014, 43: 6139-6147

16 Zhou J, Liu Q, Feng W, et al. Upconversion luminescent materials: advances and applications. Chem Rev, 2015, 115: 395-465

17 Wang X, Zhuang J, Peng Q, et al. A general strategy for nanocrystal synthesis. Nature, 2005, 437: 121-124

18 Hebbink GA, Stouwdam JW, Reinhoudt DN, et al. Lanthanide(III)doped nanoparticles that emit in the near-infrared. Adv Mater, 2002, 14: $1147-1150$

19 Li Y, Pan K, Wang G, et al. Enhanced photoelectric conversion efficiency of dye-sensitized solar cells by the incorporation of dual-mode luminescent $\mathrm{NaYF}_{4}: \mathrm{Yb}^{3+} / \mathrm{Er}^{3+}$. Dalton Trans, 2013, 42: 7971-7979

20 Jiang T, Qin W, Zhou J. Citric acid-assisted phase controlled synthesis of $\mathrm{NaYF}_{4}: \mathrm{Yb}^{3+}, \mathrm{Tm}^{3+}$ crystals and their intense ultraviolet upconversion emissions. J Fluorine Chem, 2013, 156: 177-182

21 Wang Y, Qu Y, Pan K, et al. Enhanced photoelectric conversion efficiency of dye sensitized solar cells via the incorporation of one dimensional luminescent $\mathrm{BaWO}_{4}: \mathrm{Eu}^{3+}$ nanowires. Chem Commun, 2016, 52: 11124-11126

22 Jiang T, Qin W, Zhou J. Hydrothermal synthesis and aspect ratio dependent upconversion luminescence of $\mathrm{NaYF}_{4}: \mathrm{Yb}^{3+} / \mathrm{Er}^{3+}$ microcrystals. J Nanosci Nanotechnol, 2016, 16: 3806-3810

23 Wang G, Peng Q, Li Y. Luminescence tuning of upconversion nanocrystals. Chem-A Eur J, 2010, 16: 4923-4931

24 Casaluci S, Gemmi M, Pellegrini V, et al. Graphene-based large area dye-sensitized solar cell modules. Nanoscale, 2016, 8: 5368-5378

25 Li Y, Wang G, Pan K, et al. $\mathrm{NaYF}_{4}: \mathrm{Er}^{3+} / \mathrm{Yb}^{3+}$-graphene composites: preparation, upconversion luminescence, and application in dye- sensitized solar cells. J Mater Chem, 2012, 22: 20381-20386

26 Liang Q, Li Z, Bai Y, et al. Reduced-sized monolayer carbon nitride nanosheets for highly improved photoresponse for cell imaging and photocatalysis. Sci China Mater, 2017, 60: 109-118

27 Guo K, Li M, Fang X, et al. Improved properties of dye-sensitized solar cells by multifunctional scattering layer of yolk-shell-like $\mathrm{TiO}_{2}$ microspheres. J Power Sources, 2014, 264: 35-41

28 Lee GY, Lee HR, Um MH, et al. Light scattering amplification on dye sensitized solar cells assembled by hollyhock-shaped $\mathrm{CdS}-\mathrm{TiO}_{2}$ composites. Bull Korean Chem Soc, 2012, 33: 3043-3047

29 Bakhshayesh AM, Mohammadi MR, Dadar $\mathrm{H}$, et al. Improved efficiency of dye-sensitized solar cells aided by corn-like $\mathrm{TiO}_{2}$ nanowires as the light scattering layer. Electrochim Acta, 2013, 90: 302-308

30 Wang W, Liu Y, Qu J, et al. Synthesis of hierarchical $\mathrm{TiO}_{2}-\mathrm{C}_{3} \mathrm{~N}_{4}$ hybrid microspheres with enhanced photocatalytic and photovoltaic activities by maximizing the synergistic effect. ChemPhotoChem, 2017, 1: 35-45

31 Wang P, Dai Q, Zakeeruddin SM, et al. Ambient temperature plastic crystal electrolyte for efficient, all-solid-state dye-sensitized solar cell. J Am Chem Soc, 2004, 126: 13590-13591

32 Hagfeldt A, Grätzel M. Molecular photovoltaics. Acc Chem Res, 2000, 33: $269-277$

Acknowledgments This work was supported by the National Natural Science Foundation of China (21471050 and 21501052), the China Postdoctoral Science Foundation (2015M570304), the Postdoctoral Science Foundation of Heilongjiang Province (LBH-TZ06019), Heilongjiang Province Natural Science Foundation (ZD201301), and the Science Foundation for Excellent Youth of Harbin City of China (2016RQQXJ099).

Author contributions Wang $\mathrm{G}$ designed and engineered the samples; Yu M performed the experiments; Qu Y and Pan K wrote the paper with support from Yu M. All authors contributed to the general discussion.

Conflict of interest The authors declare that they have no conflict of interest.

Supplementary information Supporting data are available in the online version of this article. 


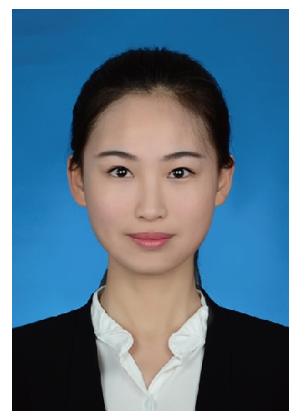

Mingqi Yu is currently a master candidate at Heilongjiang University. She joined Professor Guofeng Wang's research group in 2015 , mainly working on dye-sensitized solar cells.

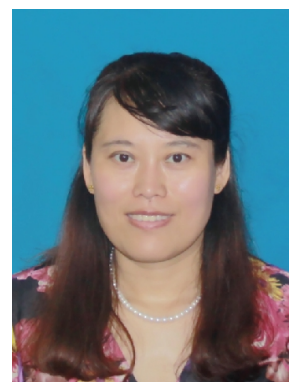

Guofeng Wang is a professor at the Key Laboratory of Functional Inorganic Material Chemistry, Ministry of Education, School of Chemistry and Materials Science, Heilongjiang University. Her current research is focused on the synthesis and application of $\mathrm{Ln}^{3+}$-doped nanocrystals.

\section{利用 $\mathrm{NaYF}_{4}: \mathrm{Er}^{3+} / \mathrm{Yb}^{3+}$ 和 $\mathrm{g}-\mathrm{C}_{3} \mathrm{~N}_{4}$ 的协同效应提高染料敏化太阳电池的光电转化效率}

于鸣琦 ${ }^{1}$ 曲阳 ${ }^{1}$, 潘凯 ${ }^{1}$, 王国风 ${ }^{1 *}$, 李亚栋 ${ }^{2}$

摘要 本文首次成功设计并得到以 $\mathrm{TiO}_{2}-\mathrm{NaYF}_{4}: \mathrm{Er}^{3+} / \mathrm{Yb}^{3+}-\mathrm{C}_{3} \mathrm{~N}_{4}$ 复合材料作为光阳极的染料敏化太阳电池. 与纯 $\mathrm{TiO}_{2}$ 和 $\mathrm{TiO}_{2}-\mathrm{C}_{3} \mathrm{~N}_{4}$ 电池相比, $\mathrm{TiO}_{2}-\mathrm{NaYF}_{4}: \mathrm{Er}^{3+} / \mathrm{Yb}^{3+}-\mathrm{C}_{3} \mathrm{~N}_{4}$ 复合电池的效率明显提高. 研究表明, $\mathrm{TiO}_{2}-\mathrm{NaYF}_{4}: \mathrm{Er}^{3+} / \mathrm{Yb}^{3+}-\mathrm{C}_{3} \mathrm{~N}_{4}$ 复合电池的 $\mathrm{TiO}_{2}-\mathrm{dye}_{\mathrm{e}} \mathrm{I}_{3}{ }^{-} / \mathrm{I}^{-}$界面阻抗小于纯 $\mathrm{TiO}_{2}$ 电 池. 此外 $\mathrm{TiO}_{2}-\mathrm{NaYF}_{4}: \mathrm{Er}^{3+} / \mathrm{Yb}^{3+}-\mathrm{C}_{3} \mathrm{~N}_{4}$ 电池具有更长的复合时间和更短的传输时间. 电池效率的提高归结于 $\mathrm{NaYF}_{4}: \mathrm{Er}^{3+} / \mathrm{Yb}^{3+}$ 和g $-\mathrm{C}_{3} \mathrm{~N}_{4}$ 的协同效应. 